\title{
KEADILAN RESTORATIF DALAM TINDAK PIDANA RINGAN DI MASA PANDEMI COVID-19
}

\author{
I Gusti Ayu Sukrisma Dewi, Anak Agung Sagung Laksmi Dewi, I Made Minggu Widyantara \\ Fakultas Hukum, Universitas Warmadewa, Denpasar-Bali, Indonesia \\ ayusukrisma05@gmail.com, laksmiidewi29@gmail.com, mademinggu21@gmail.com
}

\begin{abstract}
Abstrak
Pada saat pandemic Covid-19 ini berbagai macam kegiatan diberhentikan dari segi Pendidikan, pariwisata, perusahaan, politik, dan penyelesaian suatu perkara yang menimbulkan kerumunan atau keramaian. Dimana untuk meminimalisir penyebaran COVID-19 dalam menyelesaikan suatu duduk perkara yang ringan bisa melalui Keadilan Restoratif. Tujuan penelitian ini adalah untuk menganalisa pengaturan hukum tentang keadilan restoratif dalam tindak pidana ringan di masa pademi covid-19 serta sanksi pidana terhadap tindak pidana ringan berdasarkan keadilan restoratif. Penelitian ini merupakan penelitian hukum normatif dengan menggunakan sumber hukum primer dan sekunder. Teknik pengumpulan data dilakukan memperoleh bahan hukum yang dibutuhkan melalui studi pencatatan dan dokumentasi. Kemudian, bahan-bahan hukum tersebut diolah dengan menggunakan analisa interpretasi. Hasil penelitian mengungkapkan bahwa pengaturan tentang keadilan restoratif dalam tindak pidana ringan di masa pandemi covid-19 sangat diperlukan untuk mengatur sanksi pidana terhadap tindak pidana ringan yang didasarkan pada keadilan restoratif.
\end{abstract}

Kata Kunci: Covid 19, Keadilan Restoratif, Tindak Pidana Ringan

\begin{abstract}
At the time of the Covid-19 pandemic, various activities were suspended in terms of education, tourism, companies, politics, and the resolution of a case that caused a crowd or crowd. Where to minimize the spread of COVID-19 in resolving a minor problem, it can be done through Restorative Justice. The purpose of this study is to analyze the legal arrangements regarding restorative justice in minor crimes during the covid-19 pandemic and criminal sanctions against minor crimes based on restorative justice. This research is a normative legal research using primary and secondary legal sources. Data collection techniques are carried out to obtain the required legal materials through recording and documentation studies. Then, the legal materials are processed using interpretation analysis. The results of the study reveal that the regulation of restorative justice in minor crimes during the covid-19 pandemic is very necessary to regulate criminal sanctions against minor crimes based on restorative justice.
\end{abstract}

Keywords: Covid 19, Restorative Justice, Minor Crimes

\section{PENDAHULUAN}

Negara Indonesia adalah negara hukum, Ekatjahjana (2015) negara hukum lahir sebagai gagasan pada usaha hak asasi manusia. Penegasan konstitusi ini dimaksudkan, bahwa segala aspek pada kemasyarakatan, kenegaraan dan pemerintahan wajib berdasar aturan. Perangkat aturan yang krusial dipakai buat mengatur equilibrium dan keadilan pada segala bidang kehidupan melalui peraturan perundang-undangan tanpa mengesampingkan fungsi yurisprudensi. Hal ini memberitahukan bahwa UU memiliki kiprah yang krusial pada negara aturan Indonesia. Konsep pembentukan aturan merupakan bahwa peraturan perundang-undangan bisa dijalankan dan diterima warga, akan namun dalam kenyataannya peraturan perundang-undangan yang ada tidak bisa diimplementasikan. Hal tadi lantaran kadang kala peraturan yang telah terdapat, wajib diganti walaupun sebenarnya peraturan tadi masih relevan dengan keadaan ketika ini.

Indonesia dianggap pula menggunakan Republik Indonesia atau Negara Kesatuan Republik Indonesia, bentuk negara Indonesia merupakan negara kesatuan dan bentuk pemerintahan pada Indonesia merupakan republik menggunakan Dewan Perwakilan Rakyat, Dewan Perwakilan Daerah, Presiden yang dipilih secara langsung. Dari Sabang hingga Merauke Indonesia mempunyai aneka macam suku bangsa, Bahasa, budaya, dan kepercayaan. Akan namun Indonesia yang mempunyai 
aneka macam Bahasa, budaya, dan kepercayaan yang bhineka permanen mempunyai semboyan Bhinneka Tunggal Ika yang berarti Berbeda-beda Tetapi Tetap Satu.

Hukum adalah sistem yang terpenting dalam rangkaian kekuasaan kelembagaan berdasarkan bentuk penyalahgunaan kekuasaan dalam bidang politik, ekonomi, dan warga pada aneka macam cara bertindak menjadi mediator primer pada interaksi sosial antara warga terhadap kriminalitas yang terjadi di lingkungan. Dalam penyelesaian criminal yang terdapat bisa ditempuh menggunakan cara diadilinya pada pengadilan negeri, pengadilan rapikan bisnis negara, pengadilan militer, pengadilan kepercayaan , tergantung berdasarkan segi kejahatan yang terjadi. Yang sidangnya sanggup dikatakan terbuka buat generik juga tertutup.

Tetapi disaat pandemic COVID-19 ini aneka macam aktivitas diberhentikan berdasarkan segi Pendidikan, pariwisata, perusahaan, politik, dan penyelesaian suatu masalah yang menyebabkan kerumunan atau keramaian. Sehingga buat meminimalisir penyebaran COVID-19 buat merampungkan suatu duduk masalah yang ringan sanggup melalui Restorative Justice. Restorative Justice merupakan suatu bentuk model pendekatan baru dalam penyelesaian perkara pidana. Model pendekatan restorative justice ini sebenarnya telah dilakukan di beberapa negara memakai focus pendekatan dalam pelaku, korban, dan rakyat dalam proses penyelesaian masalah anggaran. Walaupun model pendekatan ini masih banyak diperdebatkan dalam tataran teori oleh para ahli, namun dalam kenyataannya tetap tumbuh, eksis serta mempengaruhi kebijakan pada praktek anggaran di banyak negara (Flora, 2018).

Pengertian Keadilan Restoratif atau Restoratif Justice berdasarkan Pasal 1 nomor 6 Undangundang Nomor 11 Tahun 2012 mengenai Sistem Peradilan Pidana Anak Dewasa ini biasanya warga jika terjadi suatu tindak pidana, warga cenderung menentukan memakai jalur pengadilan yang secara konsep akan membentuk keadilan, namun pada fenomena yang terjadi hal ini adalah hal yang tak gampang terjadi. Hal ini dikarenakan output yang akan ditempuh berdasarkan proses penyelesaian masalah menggunakan jalur peradilan bersifat win lose solution yang dimana berarti keliru satu pihak menang menerima yang beliau inginkan, tetapi pihak lain kalah tidak menerima apa-apa.

Dalam kenyataan contohnya ini penyelesaian kasus tindak pidana menggunakan jalur pengadilan pada umumnya mengakibatkan suatu rasa tidak adil dalam para pihak yang kalah, sebagai akibatnya berupaya buat mencari keadilan ke taraf pengadilan lebih lanjut yang akan memakan waktu. Yang pada hal ini menciptakan penyelesaian satu tindak pidana akan sebagai sangat lambat. Yang dikarenakan penegak aturan melalui jeda tempuh yang Panjang, melalui beberapa tingkatan dimulai berdasarkan Kepolisian, Kejaksaan, Pengadilan Negeri, Pengadilan Tinggi bahkan sanggup hingga Mahkamah Agung, dalam akhirnya akan terjadi penumpukan masalah yang jumlahnya nir sedikit. Apalagi sekarang disaat pandemic COVID-19 ini banyak sekali kegiatan yang harus dihentikan pelaksanaannya secara langsung di seluruh dunia, sehingga khususnya Indonesia melakukan sistem daring atau online untuk beberapa kegiatan. Hal ini dilakukan agar memperkecil penyebaran virus corona.

Adanya virus corona ini menyebabkan semakin surutnya ekonomi di beberapa negara sehingga banyak menyebabkan timbulnya kejahatan-kejahatan di berbagai belahan dunia. Dan di Indonesia khususnya di Bali beberapa lapas tempat para pelaku kejahatan tindak pidana, seorang tersangka yang belum habis masa hukumannya dibebaskan atau dikembalikan ke tempat asal masing-masing guna memperkecil penyebaran virus corona. Dari dibebaskannya narapidana yang tertera diatas, dan banyaknya tindak pidana baru yang dilakukan oleh seseorang, sekelompok orang, dan atau narapidana yang dibebaskannya. Untuk ditindak lanjuti tindak pidana tersebut yang dilakukan oleh pelaku kejahatan haruslah menempuh jalur hukum atau diadili di pengadilan, tetapi karena kondisi seperti ini bumi yang belum sembuh dari virus corona ini banyak persidangan yang dilakukan secara daring atau online. Yang bisa terhambat karena masalah signal, suara tidak didengar oleh tersangka maupun para penegak hukum yang pada akhirnya mengalami keterlambatan atau ditundanya suatu sidang tertentu. Semakin ditundanya sidang dalam satu perkara akan semakin lama keputusan akhir yang diperoleh pelaku atau korban kejahatan, ditambah lagi dengan tertundanya sidang-sidang yang lainnya.

Pada kesempatan seperti inilah seharusnya dalam penyelesaian suatu perkara bisa menggunakan solusi keadilan restorative atau restorative justice, dimana dalam penyelesaian ini bisa dilakukan secara langsung dengan tetap menggunakan protocol kesehatan yang sudah ditentukan oleh pemerintah. Jadi sebaiknya dalam situasi COVID-19 ini lebih baik menggunakan keadilan 
restoratif atau restorative justice untuk menyelesaikan sebuah kejahatan atau tindak pidana yang dilakukan seseorang atau individu. restorative justice juga menitikberatkan pada adanya partisipasi langsung pelaku, korban dan masyarakat dengan memaknai tindak pidana. Keadilan restoratif juga merupakan suatu kerangka berfikir yang baru yang dapat digunakan dalam merespon suatu tindak pidana bagi penegak dan pekerja hukum di Indonesia (Muhaimin, 2019). Adapun sifat dari restorative justice menurut Arief \& Ambarsari (2018) yaitu suatu pelanggaran terhadap manusia dan relasi antar manusia. Keadilan restoratif, dapat dilaksanakan melalui: Mediasi korban dengan pelanggar; Musyawarah kelompok keluarga; pelayanan di masyarakat yang bersifat pemulihan baik bagi korban maupun pelaku.

Namun memang benar tidak semua tindak pidana yang dapat diselesaikan dengan keadilan restorative ini, tindak pidana yang dapat diselesaikan melalui keadilan restorative ini adalah tindak pidana ringan saja. Seperti pencurian, penipuan, pencemaran nama baik. Mungkin saja untuk tindak pidana berat bisa juga digunakan keadilan ini karena dalam situasi yang seperti ini banyak juga prosedur yang harus dipatuhi, tetapi kembali lagi kepada keinginan keluarga korban untuk memilih cara yang digunakan dalam menyelesaikan suatu masalah.

Menurut Urrutab (2021) Peraturan Kejaksaan Republik Indonesia Nomor 15 Tahun 2020 Tentang Penghentian Penuntutan Berdasarkan Keadilan Restoratif sudah cukup memenuhi aspek keadilan serta memenuhi prinsip-prinsip umum keadilan restoratif. Namun demikian, perlu adanya beberapa perbaikan seperti penjelasan terkait konteks kasuistik dalam Pasal 5 dan impelementasi peraturan bagi aparat penegak hukum agar senantiasa mengedepankan hati nurani sehingga penegakan hukum di Indonesia kedepan semakin baik serta mampu mengembalikan kepercayaan publik dalam upaya penegakan hukum dan keadilan. Selain itu, di tengah masa pandemi, konsep ini sejalan dengan aturan pemerintah dalam upaya menanggulangi pandemi covid 19 sehingga tidak semua kejahatan harus diselesaikan secara pidana sebagaimana kondisi lembaga pemasyarakatan di Indonesia yang sudah melebihi kapasitas. Adapun penelitian yang dilakukan oleh Maya \& Wadjo (2021) restorative justice bukanlah mekanisme yang baru dalam menyelesaikan persoalan-persoalan hukum dalam masyarakat yang masih kental dengan sistem hukum adat. Kasus-kasus yang dapat diselesaikan dengan mekanisme ini adalah kasus-kasus dalam keluarga seperti halnya kekerasan dalam rumah tangga (KDRT). Dengan demikian, mekanisme ini sangat cocok untuk menghindari kehancuran dalam keluarga yang dapat berlanjut dengan perceraian. Namun dalam realitasnya, diterapkan juga dalam kasus-kasus kekerasan terhadap perempuan yang terjadi di luar lingkup keluarga. Sedangkan penelitian dari Sosiawan (2016) menunjukkan bahwa Restorative Justice harus dilakukan sebagai wujud perlindungan atas anak yang berhadapan dengan hukum, karena pada dasarnya ia tidak dapat dilepaskan dari konteks yang melingkupinya, sehingga tidak adil apabila ia dikenai sanksi retributif, tanpa memperhatikan keberadaannya dan kondisi yang melingkupinya.

Berdasarkan uraian diatas, maka tujuan dari penelitian ini yaitu untuk menganalisa pengaturan hukum tentang keadilan restoratif dalam tindak pidana ringan di masa pandemi covid-19 serta sanksi pidana terhadap tindak pidana ringan berdasarkan keadilan restoratif.

\section{METODE PENELITIAN}

Penulis menggunakan tipe penelitian dan pendekatan hukum normatif yang meletakan aturan menjadi bangunan sistem norma sebagai metode penelitian dalam studi ini. Yakni mengenai asas-asas hukum, doktrin, norma-norma, kaidah-kaidah terhadap suatu peraturan perundang-undangan. Sumber bahan hukum sekunder dan primer digunakan sebagai sumber bahan hukum dalam studi ini, selain itu penggunaan buku-buku literatur, jurnal-jurnal terkait juga membantu penelitian ini. Penulis memperoleh bahan hukum yang dibutuhkan melalui studi pencatatan dan dokumentasi. Bahan hukum yang telah berhubungan dengan permasalahan telah terkumpul. Kemudian, bahan-bahan hukum tersebut diolah dengan menggunakan analisa interpretasi. Hukum agar dapat menjawab permasalahan yang dibahas.

\section{HASIL DAN PEMBAHASAN}

\section{Pengaturan Hukum Tentang Keadilan Restoratif dalam Tindak Pidana Ringan di Masa Pandemi Covid-19}

Memutus perkara pidana tidak ada pedoman maupun standar tentang bagaimana menghitung beban pemidanaan yang adil bagi pelaku. penjatuhan sanksi pidana penjara, sehingga membuat rasa keadilan 
dan kepastian tidak terukur maupun tidak menentu. Yang ada hanyalah minimal dan maksimal dalam penjatuhan pidana penjara dan pidana denda. Namun didalam hal ini masih sangat jauh dari harapan keadilan dan kepastian hukum. Dalam proses penegakan hukum di Indonesia apabila seseorang melakukan tindak pidana ringan seperti, pencurian ringan, penggelapan ringan, penipuan oleh penjual, perusakan ringan, dan penadahan ringan maka akan diproses sesuai dengan hukum perundangundangan yang berlaku di Indonesia yang diatur dalam KUHP atau Kitab Undang-Undang Hukum Pidana sesuai dengan prosedur yang ditetapkan.

Namun hingga saat ini kondisi Indonesia yang belum pulih dari Pandemi COVID-19 maka sebaiknya menggunakan alternatif lain untuk melakukan pemidanaan terhadap seseorang yang melakukan tindak pidana khususnya tindak pidana ringan. Alternatif lain yang dimaksud yaitu penyelesaian tindak pidana menggunakan keadilan restoratif dan restoratif justice, yang tidak menyebabkan perkumpulan yang dapat menyebarluaskan virus corona. Bahwa restorative justice merupakan salah satu cara penanganan Tipiring yang dilakukan oleh para penegak hukum dengan mengikutsertakan pelaku, korban, dan tokoh masyarakat terkait untuk Bersama-sama mencari penyelesaian yang adil dengan menekankan pemulihan Kembali pada keadaan semula. Restorative justice merupakan bentuk yang terbilang baru dalam perkara Tipiring. restorative justice ini sebenarnya sudah digunakan di beberapa negara dengan fokus kepada pelaku, korban dan masyarakat dalam proses penyelesaian kasus hukum yang terjadi diantara mereka (Thomas, 2015). Melihat ratusan narapidana yang dilepaskan sebelum masa tahanannya habis akibat dari dampak pandemi covid-19 ini.

Dari dibebaskannya narapidana yang tertera diatas, dan banyaknya tindak pidana baru yang dilakukan oleh seseorang, sekelompok orang. Untuk ditindak lanjuti tindak pidana tersebut yang dilakukan oleh pelaku kejahatan haruslah menempuh jalur hukum atau diadili di pengadilan, tetapi karena kondisi seperti ini bumi yang belum sembuh dari virus corona ini banyak persidangan yang dilakukan secara daring atau online. Yang bisa terhambat karena masalah signal, suara tidak didengar oleh tersangka maupun para penegak hukum yang pada akhirnya mengalami keterlambatan atau ditundanya suatu sidang tertentu. Semakin ditundanya sidang dalam satu perkara akan semakin lama keputusan akhir yang diperoleh pelaku atau korban kejahatan, ditambah lagi dengan tertundanya sidang-sidang yang lainnya.

Sehingga dalam hal ini lebih baik digunakannya keadilan restoratif dan restoratif justice ini agar tidak menumpuknya kasus karena dalam keadilan ini seseorang, sekelompok orang yang melakukan tindak pidana dapat dikenakan sanksi sosial, sanksi adat maupun denda yang diminta oleh keluarga korban. Dan penggunaan keadilan restoratif ini dapat memperkecilnya penyebaran virus corona dan dapat pula memberikan sanksi pada seseorang yang melakukan tindak tindak pidana ringan. Namun perlu digaris bawahi bahwa seseorang residivis atau seseorang yang telah melakukan tindak pidana dan Kembali melakukan tindak pidana yang sama tidak dapat diselesaikan dengan keadilan restoratif dan restoratif justice ini karena jika seorang residivis terus diadili dengan cara restorative justice maka dia akan terus menerus melakukan kejahatan, maka dari itu seorang residivis harus diadili dengan hukum nasional yang berlaku di Indonesia.

\section{Sanksi Pidana Terhadap Tindak Pidana Ringan Berdasarkan Keadilan Restoratif}

Sistem pemidanaan pada Indonesia tidak bisa terlepas menurut anggaran tertulis yang bersumber menurut aturan pidana peninggalan Belanda yang ditetapkan menjadi aturan pidana materiil pada Indonesia dari Undang-undang Nomor 1 Tahun 1946 yang dikenal secara resmi menggunakan kata Kitab Undang-undang Hukum Pidana. Sistem pemidanaan yang tercantum pada Pasal 10 kitab undang-undang hukum pidana yang masih menganut kerangka berpikir retributive, yaitu menaruh balasan yang setimpal atas kejahatan yang sudah dilakukan pelaku tindak pidana. Tujuan menurut kerangka berpikir retributive menggunakan tujuan buat menaruh pengaruh jera supaya pelaku tidak mengulangi lagi kejahatannya, mencegah warga buat melakukan tindak pidana. Tetapi kerangka berpikir ini belum mampu memulihkan kerugian serta penderitaan yang dialami korban, terdapat warga yang berani melakukan kejahatan.

Walaupun pelaku kejahatan telah diputus bersalah dan menerima sanksi, tetapi syarat korban tak bisa Kembali misalnya semula. Dari adanya kelemahan- kelemahan tadi, maka muncullah gagasan mengenai sistem pemidanaan yang berorientasi dalam pemulihan kerugian dan penderitaan korban, atau yang dikenal menggunakan pendekatan restorative justice, lantaran korban merupakam pihak 
yang paling dirugikan pada suatu kejahatan. Di pada restorative justice mengakomodir kepentingan para pihak, terutama korban lantaran korban dilibatkan pada menaruh hukuman pada pelaku kejahatan. Konsep restorative justice dalam dasarnya bertujuan buat mengembalikan permasalahan pada pihak-pihak yang paling terkena imbas korban, pelaku, famili korban, pelaku, dan menaruh keutamaan dan kepentingan-kepentingan mereka. Restorative justice mengupayakan buat mementingkan keamanan korban, penghormatan, martabat, yang lebih krusial merupakan sense of control. Dengan menganut kerangka berpikir restorative justice ini diperlukan kerugian dan penderitaan yang dialami korban, keluarga korban bisa dipulihkan dari beban rasa bersalah pelaku kejahatan bisa berkurang lantaran sudah menerima maaf menurut korban dan famili korban. Tuntutan penegakan aturan yang berorientasi dalam keadilan restoratif, sangat ditentukan sang terdegradasinya praktek-praktek penegakan aturan yang sinkron menggunakan nilai-nilai kebenaran dan keadilan dan penghormatan terhadap hak- hak asasi manusia, yang sebagaimana terlihat pada masalah pencurian semangka, 3 buah biji kakao. Kondisi misalnya ini tentu sangat jauh menurut nilai-nilai yang tergantung pada substansi supremasi aturan. Sebab tujuan supremasi aturan itu sendiri merupakan buat melindungi hak-hak rakyat negara baik menurut wewenang-wewenang penguasa juga wewenang-kewenangan rakyat negara lainnya. Untuk itulah maka pada penerapan kerangka berpikir restorative justice adalah sesuatu yang sangat signifikan. Urgensi penerapan pendekatan restorative justice pada sistem pemidanaan di Indonesia juga sejalan menggunakan pendapat Marc Levin yang menyatakan bahwa pendekatan yang dulunya dinyatakan using, antic dan tradisional sekarang justru dinyatakan menjadi pendekatan yang progresif (Levin, 2005). Apa yang dikemukakan Marc Levin tadi sebenarnya tidaklah salah, karena pendekatan restorative justice telah terdapat pada sistem pemidanaan dari aturan adat. Penerapan pendekatan restorative justice pada sistem pemidanaan di Indonesia sangat dibutuhkan dan diyakini bisa menaruh manfaat baik bagi pelaku, korban, famili korban, pelaku juga bagi negara. Manfaat yang disebabkan bagi negara yaitu bisa tercapainya keadilan, kepastian aturan, kemanfaatan bagi warga, pengurangan penumpukan kasus pada kejaksaan, pengadilan dan over kapasitas Rutan atau Lapas di masa pandemic covid-19 bisa dikurangi atau dihindari. Selain itu beberapa peraturan perundang-undangan yang ketika ini berlaku di Indonesia sebenarnya jua sudah memuat nilai-nilai restorative justice. Tetapi demikian anggaran tadi belum begitu efektif pada menaruh proteksi aturan bagi korban, lantaran prosedur penuntutan ganti rugi yang belum berjalan menggunakan efektif. Selain itu menggunakan adanya pembayaran ganti rugi hal tadi nir membebaskan pelaku menurut sanksi sebagai akibatnya hal ini bisa mengurangi kerelaan pelaku buat menaruh ganti kerugian. Penerapan kerangka berpikir restorative justice pada penyelesaian kasus tindak pidana pada Indonesia mempunyai landasan yang relatif kuat, baik menurut sisi historis, sosiologis, filosofis, juga menurut sis proteksi hak asasi manusia, nilai-nilai kepercayaan yang dianut warga Indonesia dan nilai-nilai budaya warga (Waluyo, 2015).

\section{SIMPULAN DAN SARAN}

\section{Simpulan}

Pengaturan aturan restorative justice diatur pada Pasal 1 ayat (2) Nokesber, bahwa restorative justice adalah penyelesaian masalah Tipiring yang dilakukan para penegak aturan menggunakan melibatkan pelaku, korban, dan tokoh rakyat terkait buat bersama-sama mencari solusi yang adil menggunakan menekankan pemulihan Kembali dalam keadaan semula. Keadilan restoratif ini adalah contoh pendekatan baru pada penyelesaian masalah pidana. Konsep keadilan restoratif adalah sebuah konsep keadilan yang bertujuan buat memberdayakan korban, pelaku, keluarga, dan rakyat buat memperbaiki suatu perbuatan melawan aturan, menggunakan pencerahan dan keinsyafan menjadi landasan buat memperbaiki kehidupan bermasyarakat. Sebenarnya konsep keadilan restoratif ini sudah usang dipraktekan rakyat tata cara Indonesia. Mekanisme penyelesaian tindak pidana menurut keadilan restoratif ini didasarkan dalam musyawarah konsensus dimana para pihak diminta berkompromi buat konvensi menuju perdamaian dan keharmonisan. Adapun sanksi pidana terhadap tindak pidana ringan menurut restorative justice merupakan hukuman yang nestapa yang diancam atau dikenakan terhadap perbuatan yang melanggar aturan yang bisa mengganggu atau membahayakan ketertiban umum. Pada biasanya Indonesia mengenal 3 jenis hukuman yaitu hukuman pidana, hukuman perdata, hukuman administrasi. Sanksi aturan pidana diklaim menggunakan kata sanksi, aturan pidana atau sanksi diatur pada pasal 10 kitab undang-undang hukum pidana, pada hukuman perdata dikenal menggunakan kata putusan yang dijatuhkan sang hakim, 
sedangkan hukuman administrasi hukuman yang dikenakan terhadap pelanggaran administrasi atau ketentuan Undang-undang yang bersifat administratif. Tetapi masih ada pula hukuman sosial dan hukuman tata cara yang bisa dipakai buat mempertanggungjawabkan perbuatan pada ruang lingkup restorative justice. Sistem pemidanaan di Indonesia tidak bisa terlepas menurut anggaran tertulis yang bersumber menurut kitab undang-undang hukum pidana yang masih menganut kerangka berpikir retributive yang ialah menaruh balasan yang atas kejahatan yang sudah dilakukan sang pelaku tindak pidana. Dari adanya kelemahan menurut kerangka berpikir retributive, maka muncullah gagasan mengenai sistem pemidanaan yang dikenal menggunakan pendekatan restorative justice. Manfaat baik bagi pelaku, korban, keluarganya bagi negara. Manfaat yang disebabkan bagi negara yaitu bisa tercapainya keadilan, kepastian aturan, serta kemanfaatan bagi rakyat, pengurangan penumpukan masalah pada kejaksaan, pengadilan dan menghindari terjadinya over kapasitas pada Rutan atau Lapas.

\section{Saran}

Bagi pemerintah seharusnya lebih mendalami tentang penerapan pendekatan restorative justice ini untuk digunakan sebagai salah satu upaya penyelesaian perkara tindak pidana ringan baik dalam kondisi bumi yang sehat maupun dimasa pandemic ini, agar tidak terjadi penumpukan perkara, over kapasitas dan dapat menangani kerugian dan penderitaan yang dialami oleh korban. Serta paradigma penerapan pendekatan restoratif ini memiliki landasan yang cukup kuat baik dari sisi sosiologis, historis, filosofis maupun dari sisi perlindungan hak asasi manusia, nilai-nilai agama dan budaya yang dianut masyarakat Indonesia. Bagi masyarakat agar mengetahui masih ada jalur lain untuk menyelesaikan perkara pidana, selain dengan jalur pengadilan, mediasi dan pendekatan restorative justice yang dimana penyelesaiannya diselesaikan dengan musyawarah mufakat dengan mengumpulkan pelaku, korban, keluarga pelaku, keluarga korban dan RT/RW. Dengan ini pelaku dapat mempertanggungjawabkan perbuatannya dengan diberikan sanksi sosial maupun sanksi adat, dan penerapan pendekatan restoratif bagus dimasa pandemic ini selain bisa mengurangi over kapasitas dan tentunya mengurangi penyebaran virus corona dan tetap menggunakan protocol Kesehatan yang telah ditentukan. Bagi pelaku tindak pidana ringan maupun berat agar tidak mengulangi kejahatan yang pernah dilakukan karena sanksi yang diberikan bersifat nestapa.

\section{DAFTAR PUSTAKA}

Arief, H., \& Ambarsari, N. (2018). Penerapan Prinsip Restorative Justice dalam Sistem Peradilan Pidana di Indonesia. Al'Adl, 10(2), 173-190.

Ekatjahjana, W. (2015). Negara Hukum, Konstitusi, dan Demokrasi. Jember University Press, Jember. Flora, H. S. (2018). Keadilan Restoratif Sebagai Alternatif dalam Penyelesaian Tindak Pidana dan Pengaruhnya dalam Sistem Peradilan Pidana di Indonesia. University Of Bengkulu Law Journal, $3(2), 142-158$.

Levin, M. (2005). Restorative Justice in Texas Past, Present and Future. Texas Public Policy Foundation.

Maya, E. R., \& Wadjo, H. Z. (2021). Penerapan Restorative Justice dalam Penanganan Kasus Kekerasan Terhadap Perempuan Pada Masa Pandemi Corona Virus Disease (COVID-19). Jurnal Belo, 6(2), 256-275.

Muhaimin. (2019). Restoratif Justice dalam Penyelesaian Tindak Pidana Ringan. Jurnal Penelitian Hukum De Jure, 19(2), 185-206.

Sosiawan, U. M. (2016). Perspektif Restorative Justice Sebagai Wujud Perlindungan Anak yang Berhadapan dengan Hukum. Jurnal Penelitian Hukum De Jure, 16(4), 425-438.

Thomas. (2015). Hukum, Keadilan Restoratif Sebagai Alternatif dalam Penyelesaian Tindak Pidana dan Pengaruhnya dalam Sistem Peradilan Pidana di Indonesia. Fakultas Hukum Universitas Katolik St, Medan Sumatera Utara.

Urrutab, M. R. (2021). Konsep Keadilan Restoratif dalam Penegakan Hukum Pidana Di Masa Pandemi Covid 19. Syntax Idea, 3(7), 1690-1707.

Waluyo, B. (2015). Relevansi Doktrin Restorative Justice dalam Sistem Pemidanaan di Indonesia. Hasanuddin Law Review, 1(2), 210-226. 